\title{
THE ROLE OF SERVICES IN RURAL INCOME: THE CASE OF VIETNAM
}

\author{
M. Ataman Aksoy and Aylin Isik-Dikmelik ${ }^{1}$
}

\begin{abstract}
This paper investigates the role of services in the household response to trade reforms in Vietnam. The relative response of the households and income growth after a major trade liberalization in rice are analyzed aiming to answer the following questions: What type of households, in which locations, having access to what type of services, benefited more from the reforms? The focus is on services that have an impact on transaction costs (roads or quality of roads, public transportation, access to credit, extension services, and availability of markets in communication services) because transaction costs are often cited as a barrier to rural households in responding to the price changes and increased incentives offered by trade and other policy reforms. The results suggest that availability of production related services contributes positively to the impact of trade reforms. Although most of the service variables have a positive and significant effect on growth in income, some that are expected to have an impact are not significant. This may be explained by the exceptional coverage of infrastructure services in Vietnam even before the reforms. When service availability is very similar across different localities, household characteristics become more important in determining the response.
\end{abstract}

Keywords: Response to trade reform, Vietnam, production related services.

\section{World Bank Policy Research Working Paper 4180, March 2007}

The Policy Research Working Paper Series disseminates the findings of work in progress to encourage the exchange of ideas about development issues. An objective of the series is to get the findings out quickly, even if the presentations are less than fully polished. The papers carry the names of the authors and should be cited accordingly. The findings, interpretations, and conclusions expressed in this paper are entirely those of the authors. They do not necessarily represent the view of the World Bank, its Executive Directors, or the countries they represent. Policy Research Working Papers are available online at http://econ.worldbank.org.

1

World Bank. We would like to thank Bernard Hoekman, Aaditya Mattoo, Don Mitchell, Alessandro Nicita, Guido Porto, and an anonymous referee for helpful discussions and comments. This paper is part of a World Bank research project on trade in services supported in part by the UK Department for International Development. 


\section{INTRODUCTION}

Rural poverty in many low income countries has been persistent despite significant policy and investment programs to reduce it. Part of this is explained by the predominance of subsistence farming, especially in Sub-Saharan Africa where the share of own consumption in household income averages 30 percent, and can be as high as 50 percent (i.e. Ethiopia). Increasing the productivity and incomes of smallholder agriculture through increased production of cash or export and food crops has often been seen as a key requirement for sustained growth and poverty reduction in countries where large rural populations depend on agriculture. The high transaction costs, food insecurity, lack of both household assets and rural services infrastructure, and high taxation of agriculture are cited among the main causes of the low returns and slow responses to the policy and institutional changes.

The objective of both trade and agricultural marketing reforms over the last few decades was to induce farmers to increase their productivity and output through reducing the costs of transactions and increasing the profitability of agricultural production. Similarly, many agricultural projects were also aimed at facilitating this shift through the creation of infrastructure, knowledge, and capital.

Vietnam is a poor country where the majority of the households (almost 80 percent) live in rural areas and are engaged in agricultural activities. In 1993, the PPP adjusted per capita income was only $\$ 1172$ which was about the same level as many Sub Saharan Countries (i.e. Ghana, Cameroon, and Senegal). In Vietnam, poverty is a predominantly rural phenomenon, in 1993 rural poor constituted 64 percent of the rural households. Hence, the issues of commercialization and supply response were the keys to its growth and poverty alleviation.

Vietnam also had significant agricultural reforms in the 90s as part of the "doi moi" reforms to move towards a market economy ${ }^{2}$. One such major reform was the liberalization of rice marketing in $1997^{3}$; the export quota was liberalized until it was no

\footnotetext{
${ }^{2}$ Land titling reforms and liberalization of fertilizer markets are among such reforms. See Niimi et.al. (2003) for a detailed description of "doi moi" reforms.

${ }^{3}$ Although international trade in rice was liberalized earlier, this was partial as export quota was still binding. The full liberalization took place in the first part of 1997.
} 
longer binding. Complementing this liberalization was the lifting of internal trade restrictions of rice. Before this domestic reform, the flow of rice from South (where more rice is produced and there is a surplus) to North was restricted to encourage self sufficiency in each region. The internal trade ban coupled with the binding export quota caused low prices of rice in the South and high prices in the North. The increase in export quota and the lifting of internal restrictions has led to increased rice prices (in real terms) everywhere but proportionally more in the South (Benjamin \& Brandt, 2004). Along with rice, fertilizer markets were also liberalized which led to a decline in fertilizer prices.

The response in Vietnam to these reforms was overwhelmingly positive. Between 1993 and 1998 (for which there is household survey data), real incomes of rural households increased by almost 60 percent. This is unusually rapid growth for rural communities, corresponding to a real income growth of almost $10 \%$ per annum. Moreover, more than half of this growth in rural areas was caused by the growth in agricultural incomes (Isik-Dikmelik, 2006). The household response to these reforms could be conditional on the household characteristics and service availability. It is important to find out the reasons for this rapid response and to determine who responded by how much.

The determinants of the rate of supply response can be separated into factors that are intrinsic to the household, and factors that are external to the household. Intrinsic to the household are the household size, the education and skills of the household members, and the capital stock of the household including land. Factors external to the household have to do with the availability of services and infrastructure, both physical and market, in rural communities. Thus, the survey data allows the measurement of the rate of supply response of households with different initial characteristics to these reforms and also measure the role of the availability of services infrastructure on these response rates.

Many farm households may not be able to shift into commercial crop production and sales as a response to trade reform even if it is a much more profitable activity because (small scale) farmers face high transaction costs in marketing their products or receiving modern inputs (Key, Sadoulet, and de Janvry, 2000). Transaction costs differ across households due to differences in the availability and efficiency of markets for their products and inputs, assets ownership, access to other services, market information, and 
transportation costs. When those transaction costs are higher than the benefits from shifting to marketable agricultural products, then the household will not participate in the market and rely on subsistence farming. ${ }^{4}$ While part of the transaction costs have to do with the low human and physical capital of the households (education, land, physical assets for farming etc), a very important part has to do with the lack of basic infrastructure services supplied by the public and private agencies in the localities where the poor farmers are living. These are services such as roads, electricity, credit, existence of markets etc. The absence of these infrastructure services forces the households to delink themselves from the markets, even if their household characteristics would allow them to participate effectively if they were located in areas with better infrastructure services. $^{5}$

The relationship between income and availability of services, especially infrastructure services, assumes that the non-availability of basic, production-related, services segments the markets in such a way that households who have the right household characteristics to respond to market signals cannot do so if the key services are not available in their communities. Thus the impact of services variables will be very significant in explaining the incomes and the responses of households. If the services infrastructure improves across the country in question, the impact of these services variables will diminish, characteristics internal to the household would be the determining factors of income. In many cases, richer households, or households endowed with higher levels of human and physical capital have the capacity to respond to the reforms, even if there are infrastructural barriers. Thus, the existence and efficiency of rural infrastructure would also be pro-poor if it allows the households with lower physical and human capital to respond effectively in higher value added markets and respond to reforms that are aimed at increasing the supply response. ${ }^{6}$

\footnotetext{
${ }^{4}$ Cadot, Dutoit and Olarreaga (2005) showed that in the case of Madagascar's subsistence farmers these transaction costs can be equivalent to 1 to 2 years of the value of their marketable production.

${ }^{5}$ A related reason for the lack of supply response to trade reforms and price changes is the need for food security and risk aversion caused by the lack of well developed local food, labor and credit markets. This leads farmers to allocate a significant portion of their land and labor to subsistence food production and not fully respond to higher cash crop profitability (de Janvry, Fafchamps, and Sadoulet, 1991).

${ }^{6}$ It is an interesting question whether the ability to participate in markets is a continuous variable of the household characteristics conditional on a level of infrastructure availability, or if there are critical minimum levels of both household and/or infrastructure that are necessary for integration into the markets. In this study we assume that these relationships are continuous.
} 
With that in mind, there are a few characteristics that differentiate Vietnam from other low income countries. First, it had a much better coverage of basic services infrastructure across most regions even during $1993 .^{7}$ According to the data both on services availability and the perceptions of commune leaders, the infrastructure has improved significantly during this five year period. The key question asked in this paper is what type of households, in which locations, having access to what type of services, benefited more from the reforms of the 1990s? Thus, the question is of a relative response of the households and income growth rather than the absolute response of the rural economy. An equally important question would be to test whether the overall fast response observed in Vietnam was due to the better coverage of services. Given that almost all regions have access to the basic services infrastructure, it is very hard to show that the fast overall growth is related to the better services availability in Vietnam. For that, one would need to compare Vietnam to other countries, however, to the best of our knowledge, comparable studies of this type do not yet exist.

In order to answer the question of which services and household characteristics have an impact we estimate the determinants of income growth using household data for a panel of households. To avoid simultaneity we only include initial household characteristics and services, which are predetermined, and examine their impact on income growth. Our results show that overall service availability and quality has a positive impact on income growth. More specifically, access to electricity, daily markets, and credit, quality of roads, and a higher initial level of integration into the market had a positive impact on growth. On the other hand, the availability of extension services, public transportation, and communication services were not significant.

The rest of the paper is organized as follows. The next section describes the data and presents detailed discussions of the availability, quality, and access to services across regions and income levels, and the production related services in Vietnam. Following this discussion, Section 3 specifies the variables used in the empirical analysis, illustrates the

\footnotetext{
${ }^{7}$ In addition to the existence of a major reform, Vietnam as a case study was picked since it was thought that there would be generally low quality of services and there would be regions or communities with very limited and uneven services access. However analysis of data showed that the services coverage was more extensive and better than other low income countries. Even by 1993, Vietnam had managed to create the basic services infrastructure in rural areas.
} 
empirical approach and provides a discussion of the results. Section 4 provides concluding remarks.

\section{SERVICE AVAILABILITY AND WELFARE: INSIGHTS \& OBSERVATIONS}

\subsection{Data}

Our analysis is based on the panel data from Vietnam Living Standards Survey (VNLSS) for 1992/1993 and 1997/1998. In addition to detailed information on household activities, these surveys include a very detailed community questionnaire and have information on the same communities and households for a subset of households in both years. This allows us to use the data in a panel form, which eases some of the statistical problems $^{8}$. The first round of VNLSS was conducted from September 1992 to October 1993 and included a self weighted sample of 4800 households with two strata (urban and rural), while the community questionnaires were administered only in rural areas; a total of 120 communes. In the second round 6000 households were interviewed, 4305 of which were previously interviewed households, while the community questionnaire was administered to both rural and minor urban areas (156 communes). The data used in this study is collected from the same 111 rural communes and about 3300 rural households in both 1993 and $1998^{9}$. Unfortunately, the detailed information on the quality of some of the key services is only available in 1998, making both the detailed analysis of the impact of quality of services and the impact of the changes in that quality difficult. This reduces the precision of some of the service variables, and might cause some of the service quality variables seem not to have an impact.

\subsection{Basic service availability}

As stated previously, Vietnam is almost unique among developing countries when it comes to basic service coverage. Figure 1 shows the distribution of some of the basic service availability for the years 1993 and 1998. Specifically, even in 1993, almost 88 percent of rural communes had electricity, 85 percent had roads (as opposed to 45 percent

\footnotetext{
${ }^{8}$ The panel nature of our data ensures that we control for unobserved household characteristics, as opposed to repeated cross-section data.

${ }^{9}$ Only rural communes in both years were included as those were the only ones interviewed for the community survey in both years (those that switched from urban to rural or vice versa were not included, in addition to those that underwent administrative changes).
} 
in Madagascar; Nicita, 2006), 64 percent had daily or periodic markets, and 96 percent had basic health services (as opposed to 31 percent in Malawi; Balat and Porto 2006). Among the individual households, 36 percent of rural households had electricity at home which increased to 71 percent of households by 1998. Similarly, almost 14 percent of households had access to formal finance, and had borrowed from a Government Bank, and this ratio had increased to 30 percent by $1998^{10}$.

Figure1. Average Access to Major Services

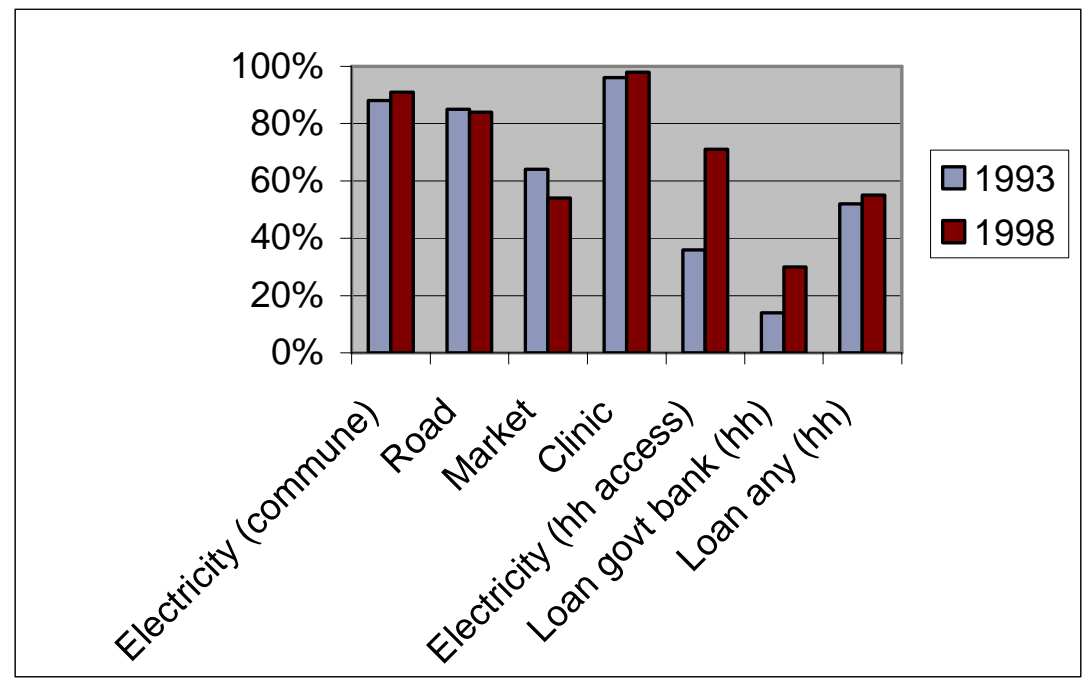

The coverage of basic services in other areas is also very extensive. In 1993, 98 percent of rural communes had primary schools, 88 percent had lower secondary schools and 8 percent had upper secondary schools ${ }^{11}$. Almost 20 percent of communes had agricultural extension services within the commune and even more within 10 kilometers. And 50 percent of communes had public transport that passes through the commune.

These numbers are extremely high for low income countries whereas most other countries have not been able to supply basic services to their rural households. In a sense this makes the analysis of the impact of basic services and real income or supply response very difficult because almost all areas are covered by these services.

\footnotetext{
${ }^{10}$ While initial ratio for access to credit is similar in Madagascar, 10 percent in 1993, the access did not change much over time and is around 9.5 percent in 2001 (Nicita, 2006).

${ }^{11}$ The ratios for the school coverage are not exactly comparable between 1993 and 1998 due to different questionnaire design, thus have not been presented here. However, it is unlikely that the access to educational services declined between 1993 and 1998.
} 
Figure 2 shows the distribution of services across the seven agroecological regions of Vietnam. These regions are Northern Uplands (NU), Red River Delta (RR), and North Central Coast (NCC) in the North, and South Central Coast (SCC), Central Highlands (CH), South East (SE), and Mekong Delta (MD) in the South. These figures illustrate that the coverage across the regions for most basic services is sufficiently close and are very high. The electricity variable denotes the share of households that have electricity at home. Road access is defined as whether there is a road that goes through the commune ${ }^{12}$. Market access is defined as the share of communes that have a permanent market in the commune ${ }^{13}$. On the other hand, access to credit variable is illustrated by the share of households that have received loans from a formal government bank. The private banking system is almost non-existent.

\section{Figure 2a-2f. Regional Access}
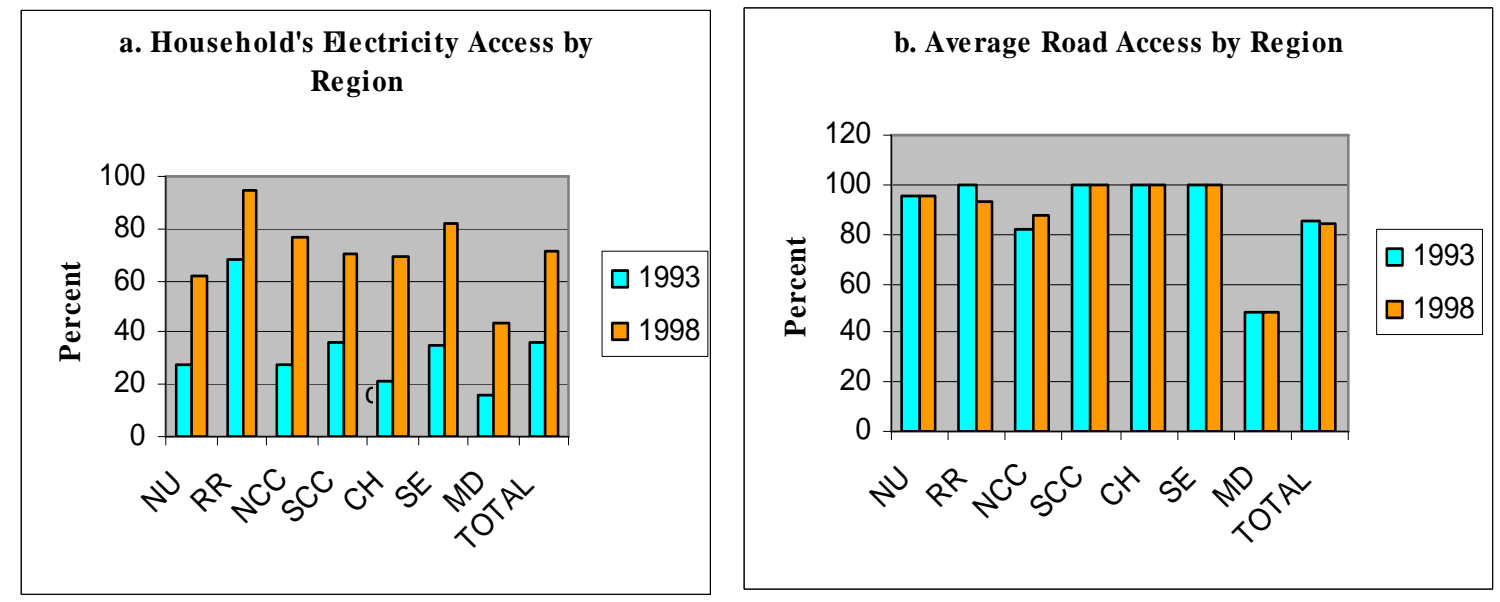

\footnotetext{
${ }^{12}$ The road quality variable only exists for 1998. See section 2.4 for details of the transportation availability.

${ }^{13}$ There are also periodic markets which, when added together does cover more than half of the communes.
} 

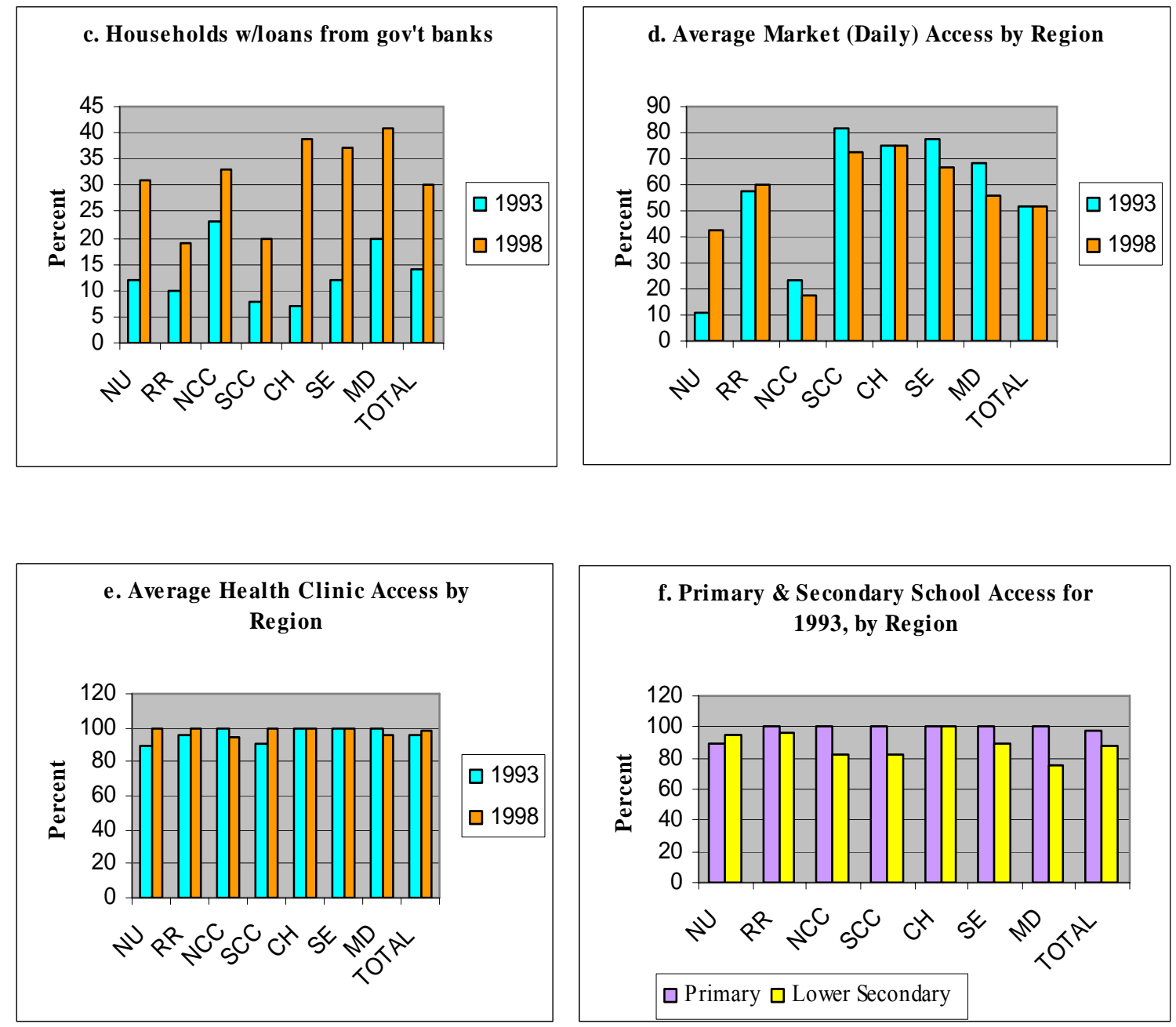

This extensive service coverage also has little regional differences, despite the fact that the income levels of the regions are quite different. Even in the least developed regions, the minimal level of service is available. This is especially true of basic education, roads, health clinics, and markets. In cases where the basic infrastructure was limited in 1993, such as household electricity connections and formal credit, there is significant growth in coverage between 1993 and 1998. In cases where there are regional differences, most of these differences may not be as significant as they seem. For instance, the Mekong Delta region has low road access however, it turns out that waterways are widespread in this region, which enables cheaper transportation.

The share of communes that lacked all three services; roads, daily markets, and electricity, constituted only 4.6 percent of the communes. 46.6 percent of communes had all three services. If the communes with waterways are added to the number of 
communes that have roads, and periodic markets are added to the communes with daily markets, then the share of communes that lack all three services and the share of communes that have all three services are 1 and 53 percent respectively.

\subsection{Services and the Poor}

Another way of examining the issue of service availability is to see whether poorer households have similar rate of access to basic services as the richer households. For a rough categorization of households according to their income level, we use adjusted (for regional and time differences) per capita expenditure deciles for 1993. Poor households are defined as the lowest 4 deciles of the whole population ${ }^{14}$. The middle income households are in middle 4 deciles (deciles 5-8), while rich households represent the top 2 deciles in income distribution.

Figure 3a-3e. Access to Services by Income Level
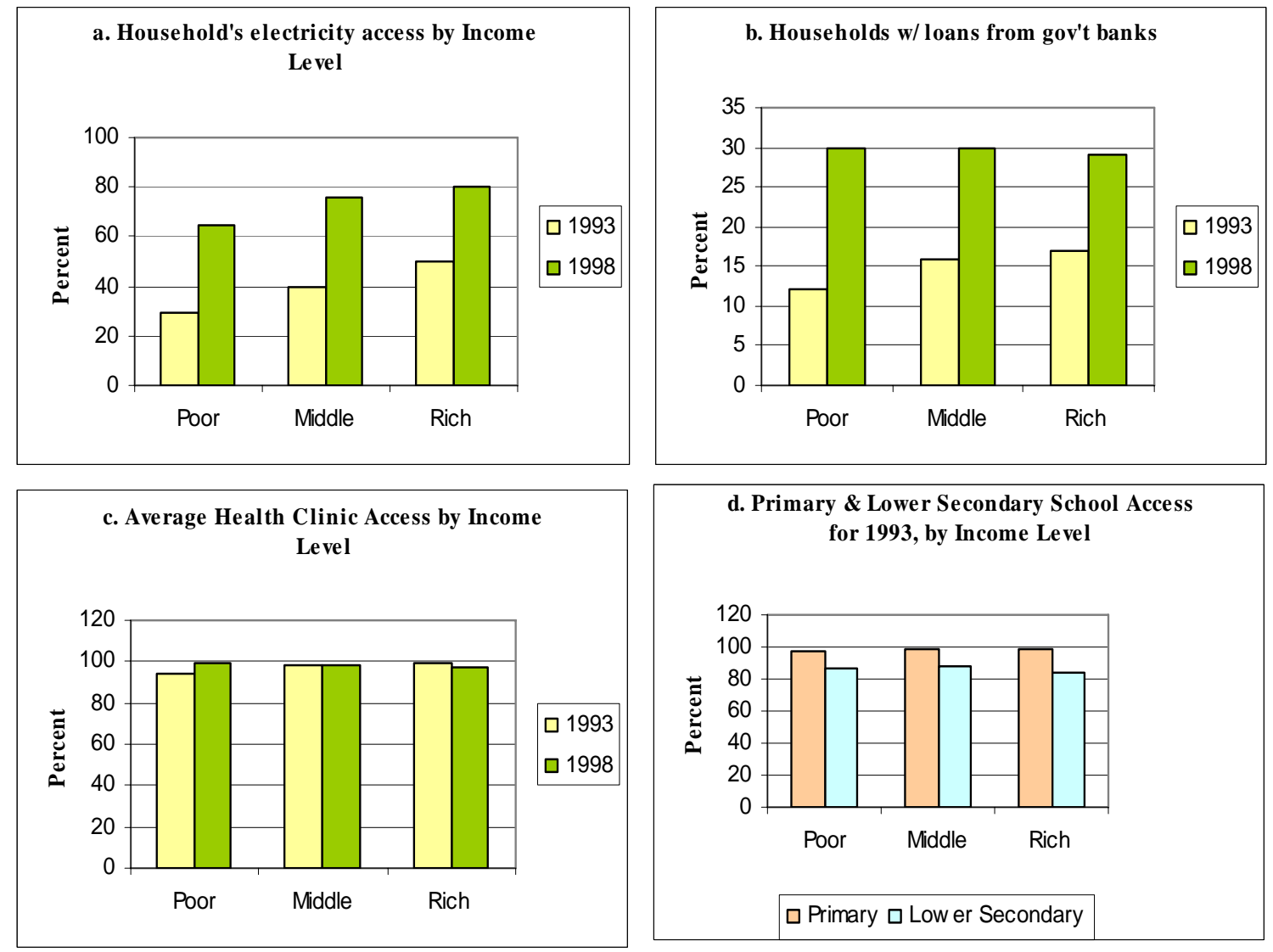

\footnotetext{
${ }^{14}$ This is a conservative categorization of the poor, as the overall poverty incidence was $58 \%$ and $64 \%$ for rural areas in 1993, Glewwe et.al. (2000)
} 
Figure 3 shows the distribution of access to basic services by poor and rich groups. The access for basic services such as health clinics and education are about the same among the poor and the rich households. In other services, such as electricity at the household level and receiving a formal sector loan, there are some differences ${ }^{15}$. In electricity, the gaps between rich and poor exist but have gotten smaller over time. It is amazing that by 1998 more than 60 percent of poor rural households had electricity connections at home. The coverage had doubled in five years. The most dramatic change is in access to formal credit, where in 1998, the share of poor and rich households that had received a loan from a bank were equalized. Hence, one can conclude that the poorer households are not much worse off than the richer households in terms of access to basic service infrastructure.

\subsection{Transport Structure, Markets and Credit}

There are a series of production-related services (such as access to credit, transportation etc.) that are important in households' production decisions. In this subsection we describe the availability and quality of these services for Vietnam in detail.

In most of the literature, one of the most important infrastructure variables is the existence and efficiency of the transport system. Having a good transport system lowers the cost of doing business and lowers the margins between market and producer prices. In measuring the quality of transport, there are a series of variables that can be considered as the measure of transport efficiency and availability. As illustrated in Fig. 2.b, the road access in Vietnam is prevalent, only in the Mekong Delta there is limited road access. However, as mentioned before, in this area where the road network looks like deficient, there are waterways that are used for transportation. In the Mekong Delta in 1998, only 48 percent of the communes had roads but 92 percent also had waterways which were used for transportation. When both roads and waterways are added together, almost all the communes had some kind of transport going through the commune.

\footnotetext{
${ }^{15}$ One should remember that these two services are among the ones where historically the poor have been kept out.
} 
In terms of the quality of roads, the data only exists for 1998. In 1998, 21 percent of the households lived in communes that did not have a road, and of these 21 percent, 14 percent had waterways, leaving only 7 percent of the households with no transportation access. Similarly, of the 23 percent of households who lived in communes with dirt roads, 3 percent of them had access through waterways. Households living in communes with waterway access are treated separately from the ones with the roads, and the roads are separated into 3 quality levels. Of these, only 7 percent of households had no access either through waterways or through roads. And 11 percent live in communes with asphalt roads.

As Figure A.1 in the Annex illustrates, the quality of roads as measured by the passability ${ }^{16}$ has an important impact on household welfare and market integration ${ }^{17}$. Households that have access to at best partially passable roads, without alternative transport structure (i.e. waterways) are less commercialized compared to those that have access to full quality roads or waterways.

In Vietnam the households' commercialization (market participation) or the ability to produce crops for sale are strongly related to the quality of the transport they have access to. However, the road quality as measured by the type of road (Dirt, Gravel, etc) turns out to be not as important as the passability of the road. Consequently, the condition of the road seems to matter more in measuring the transport costs in Vietnam. On the other hand, other transport related variables such as the existence of public transportation, or the frequency of it does not seem to have any significant effect on both the levels of income and its growth.

Subsequent to the transport system, the second most important variable that is used in the literature (for having a significant impact on income) is the existence of product and input markets. In Vietnam, almost half of the households lived in communes that had a permanent daily market. Other communes also had periodic markets. Since little information is available about the frequency or the specific role of these periodic markets, we will focus on the daily markets.

\footnotetext{
${ }^{16}$ Fully passable category also includes waterways.

${ }^{17}$ Market integration is proxied by two commercialization ratios. First is the ratio of crop sales to gross agricultural income and second is the ratio of crop sales to total income.
} 
The share of communes that have a daily market have not increased significantly between 1993 and 1998. Fig 2.d shows the share of communes in each region. There are significant differences in the regional coverage. In some regions the share of communes that have daily markets decline between 1993 and 1998. It is not clear whether this is due to the survey design or the improvements in transport allowing the markets to be consolidated across communes.

Figures A.2 illustrate whether the existence of daily markets are related to some of the important variables, such as income, commercialization and the share of cash crop income. First, the average incomes of households living in communes with daily markets are higher than those without markets and this difference is still present in 1998. As expected, the agricultural commercialization ratio is higher in communes with daily markets, but this difference was eliminated in 1998. In the case of cash crops, the households who lived in communes with markets had a higher share of income from cash crops but this relationship was reversed in 1998. We do not have a credible explanation for this reversal at this time.

In many countries, the existence of credit is one of the main determinants of being a commercial producer ${ }^{18}$. In this view, credit or other independent cash income can be used to overcome the fixed costs of entry in the market (for example to buy a donkey or a water pump, to acquire organic certification, or to build a better road from the plot to the main road). In addition to credit, households have the choice of easing the cash constraints through working as laborers within the region, working as laborers outside the local market, or producing for the market. In general, the commercialization ratio as well as the cash crop income shares can be used as proxies for cash income along with the availability and use of credit.

The share of income originating from cash crops was about 5 percent of income in 1993 and only increased to 7 percent in 1998. Regionally, the differences are also marked where only two regions are specialized in cash crops. These are South East and Central Highlands ( $15 \%$ and $33 \%$ respectively) and it is mainly coffee production that creates the high cash crop income shares in these regions (Figure 4).

\footnotetext{
${ }^{18}$ For example, in case of cotton producers in Zambia, the availability of credit has determined both the number of farmers and the amount of output (Balat and Porto, 2005). Similarly, in Tanzania, the output of tobacco has been related to the amount of credit extended (Mitchell, 2004).
} 
Figure 4. Average Share of Cash Crop Income by Region

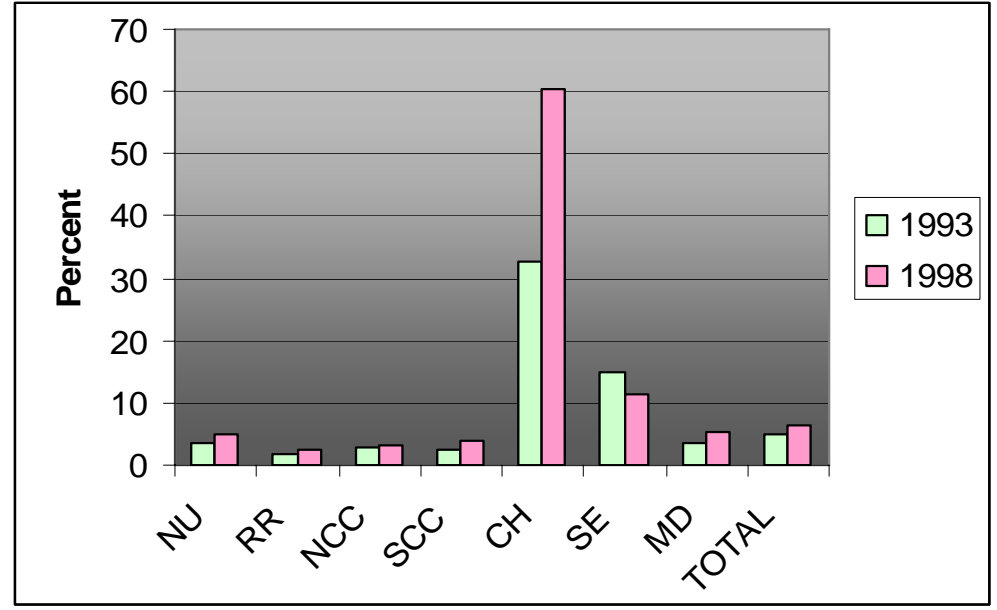

In credit access, there has been a significant increase in the amount of credit used and an improvement in the structure of sources of borrowing. The ratio of total loans of households to their income has increased from 11 percent to 25 percent. The most important change has been in the role of formal banking institutions in supplying credit. The share of loans from Government banks in total household income have increased from 1 percent of income to 13 percent. The increases have been more dramatic in regions where the incomes have grown the fastest and where cash crop shares are large. The regional differences are significant and, especially in the South, the overall credit use have expanded from 5 percent to 30 percent of income and the share of credit from the formal banking systems have increased from 2 percent of income in 1993 to 18 percent. Since the real income in South has increased by 58 percent during this period, the expansion of formal credit has been very significant.

Table 1. Real Income growth by Government Loan Status in both years

\begin{tabular}{|c|c|c|c|c|c|c|c|c|}
\hline \multirow[b]{2}{*}{ Status for Government Loan } & \multirow{2}{*}{$\begin{array}{l}\text { Mean of } \\
\text { Growth } \\
\text { Rates }\end{array}$} & \multirow{2}{*}{$\begin{array}{l}\text { Share } \\
\text { of HHs }\end{array}$} & \multicolumn{2}{|c|}{$\begin{array}{l}\text { Share of } \\
\text { Cash Crop } \\
\text { Income }\end{array}$} & \multicolumn{2}{|c|}{$\begin{array}{c}\text { Commercialization } \\
\text { Index } \\
\text { (Agnomen) }\end{array}$} & \multicolumn{2}{|c|}{$\begin{array}{c}\text { Real HH } \\
\text { Income } \\
\text { (in 98prices) }\end{array}$} \\
\hline & & & 1993 & 1998 & 1993 & 1998 & 1993 & 1998 \\
\hline No loan in either year & 46 & 63 & 4 & 5 & 17 & 22 & 6,951 & 11,129 \\
\hline Loan in 93, No loan in 98 & 40 & 7 & 3 & 5 & 22 & 25 & 9,667 & 13,144 \\
\hline Loan in both years & 50 & 8 & 8 & 9 & 25 & 31 & 9,453 & 14,829 \\
\hline No Loan in 93, Loan in 98 & 52 & 23 & 7 & 10 & 21 & 27 & 7,838 & 12,944 \\
\hline
\end{tabular}


Table 1 presents the income growth and its relationship with formal and total credit access $^{19}$. This table illustrates that the households who had formal credit in 1993 and lost it in 1998 had the lowest income growth rates. Households that had no formal credit had slightly higher growth rates. The households that had credit in both years and those that didn't have credit in 93 but got it in 1998 had the highest income growth rates. The results show that while having had a loan is somewhat significant in generating income growth, the effects are not as large as observed in other low income countries. For example in Zambia, almost all the response in cash crop production (cotton) and income growth could be attributed to the availability of credit and input supplies. Table 1 also shows that the households that had access to formal credit had higher cash crop production and more importantly, had greater commercialization ratios. In addition, the increase in cash crop as a source of income is the highest for households who increased their access to credit between two years.

Finally, the credit might be taken out for many purposes, not necessarily just for agricultural growth and increases in output. Therefore, the share of households who received loans for agriculture purposes was also analyzed. The ratio of the amount of agricultural loan to total income of the household is used as a proxy for initial access to agricultural credit. Table 2 presents the growth in income and proxies for commercialization, for households who have access to agricultural credit and those who do not (or choose not to). The differences are striking across the board. Households that had formal agricultural credit have higher incomes to start with, experienced faster income growth, and are more integrated into the market according to our three commercialization proxies.

Table 2. Market Integration and Growth by Agricultural Loan in 1993

\begin{tabular}{lccccc}
\hline $\begin{array}{l}\text { Agricultural Loan } \\
\text { Status }\end{array}$ & $\begin{array}{c}\text { Initial } \\
\text { income }\end{array}$ & $\begin{array}{c}\text { Growth in } \\
\text { Income }\end{array}$ & $\begin{array}{c}\text { Commercializatio } \\
\text { n Ratio (Ag) }\end{array}$ & $\begin{array}{c}\text { Commercialization } \\
\text { Ratio (Income) }\end{array}$ & $\begin{array}{c}\text { Share of Cash } \\
\text { Crop Income }\end{array}$ \\
\hline No Agricultural loan & 7,405 & 45.89 & 17.68 & 19.27 & 4.38 \\
Agricultural loan & 7,877 & 51.59 & 22.91 & 32.24 & 6.43 \\
\hline
\end{tabular}

\footnotetext{
${ }^{19}$ The mean of growth rates are the unweighted average of each household's mean income growth. In this measure, each household's income growth rate is given equal weight.
} 
In sum, credit seems to have an important relation with household welfare in Vietnam. It works both directly on income growth and through increased market integration as evidenced by cash crop income shares and commercialization indices.

\section{REFORMS AND THE DETERMINANTS OF INCOME RESPONSE}

The overall growth of income in Vietnam between 1993 and 1998 was remarkable. Real total household income in rural areas increased by almost $50^{20}$ percent; most of this increase was due to increases in agricultural incomes (Isik-Dikmelik 2006). This was a broad-based expansion in the entire rural sector rather than growth in only food crops or cash crops. The role of policy changes in this were corroborated by the perceptions of households as well. In the 1998 survey, as part of the community questionnaire, it was asked whether the communes felt that there had been an improvement in the economic situation. More than $95 \%$ of the communes (106 communes out of 111) replied that things had improved while 3 communes said that things had gotten worse and 2 said they had stayed the same ${ }^{21}$. Among the 106 communes where they felt that things had improved, 92 communes or 87 percent replied that it was due to the changes in agricultural policies. Another 6.7 percent said that the reason for the improvement was the expansion of the non farm economic activity. The overwhelming acknowledgement that the improvements were caused by policy changes supports the hypothesis that it was the reform that led to the supply response.

The analysis of the impact of reforms on household welfare generally falls under one of two main approaches 1) ex-ante studies where change in prices due to a trade liberalization are simulated and then in turn used to estimate the change in household welfare and 2) ex post econometric studies where the data before and after the policy change is used to estimate changes in household welfare ${ }^{22}$. Dercon (2005), Nicita (2004),

\footnotetext{
${ }^{20}$ This growth rate is the unweighted averages of the household growth. The growth in mean (weighting the total growth by incomes) for the rural areas turns out to be 60\%, (Isik-Dikmelik-2006, Benjamin\&Brandt2004)

${ }^{21}$ Of the 3 which felt that things had gotten worse said it was because of a disaster and the 2 communes that have said that things had stayed the same gave disasters or bad weather as the reason.

${ }^{22}$ For both of these approaches, both impact analysis and analysis allowing for behavioral responses have been used in the literature.
} 
and Porto (2003) are among the few studies that employ the latter approach ${ }^{23}$. In this paper we adopt the latter approach and use VNLSS 1993 and 1998 to estimate the determinants of growth in income and especially the role of services in this growth.

There are a series of service variables that have been highlighted in the literature as critical to significant supply response. The first set of these relate to the availability of cash income for the households. Cash income, whatever its source, allows the farmer to buy inputs such as fertilizer, capital inputs and labor, thus increasing the yields and output. The variables used as a proxy for eliminating the cash constraint are the availability and magnitude of credit, and the role of cash crops.

The positive links between cash crop and food production works through two channels. The first are synergies at the household level and the second are regional or location specific spillover effects. In many cases, due to the lack of credit, extension, and other sources of cash income, food crop farmers have no access to inputs such as fertilizer and seeds that could be obtained if the farmer became a part of a cash crop scheme. Even when there are no explicit cash crop schemes, the cash and credit necessary for intensification of food crop production can be obtained through the sale of cash crops. Lump-sum investments can be paid using the receipts associated with cash crops. Finally, knowledge and extension services can be obtained through cash crop schemes. The regional spillovers take place when cash crop trading attracts investments into the region for inputs, storage, and other market institutions and infrastructure. These market institutions and infrastructures can equally be used by food producers and can increase the returns to smallholder food production. Moreover, the existence of cash crop income and credit allows the households to obtain inputs such as fertilizer and gain access to markets.

One variable that determines the probability of the household participating in commercial crop production is its physical location. In particular, agro-climatic conditions are important. Not all crops can be efficiently produced in each locality. For example, the most important cash crop in Vietnam is coffee and is only produced in the Central Highlands (and in a less intense form in Southeast). In this region the average share of cash crop income in total income is 33\% (60\%) in 1993 (1998), while it is only

\footnotetext{
${ }^{23}$ Reimer (2002) and Goldberg\& Pavcnik (2004) provide a good survey of the literature.
} 
around 3.8\% (4.6\%) in other regions. ${ }^{24}$ Similarly, in the Mekong Delta, the cash income originates primarily from the sales of rice. In the South East and SCC it is the non-farm income (industrial wages and business income) that create the cash income.

Second, and more important for our purpose, is the availability of those services that would lower the transaction costs (Key, Sadoulet, and de Janvry, 2000) and increase the profitability of agricultural production for the households. These are electricity, transport, markets, and public transportation. The extension services and other technical advice improve information and farming knowledge, which would have an independent impact on the household incomes.

We utilize proxies of these variables in our estimation. The number of months that the roads are passable is an indication of the road's quality. But this question was only asked for the roads and does not cover the waterways. In order to reduce the impact of the availability of waterways, we define a new variable that captures the quality of the road (i.e. the months road is impassable) when there is no waterway available. If there is waterway available then the quality of the roads may not have such an impact as there would be an alternative form of transportation. In addition, the availability of daily markets, communication services (public phone or post office), and public transportation are also employed. We also use access of household to electricity, share of agricultural credit in income (as a proxy for access to credit for agricultural production), location of extension services, and whether household received technical advice as our service variables.

While the regional variables (services) are very important, within these localities, household characteristics determine whether an individual household will take advantage of improved incentives created by reforms. The most important determinants of being a commercial producer are the initial wealth measures, capital, land size etc. and other characteristics of the household, such as the age and the education of the household head (proxy for ability to change and innovate, as well as experience), the size of the family (risk and labor supply constraints), etc. (Bramble and Porto, 2005).

\footnotetext{
${ }^{24}$ This is why we usually observe the predominance of a single or a few cash crops in each locality. It is because the necessary economies of scale are needed for the successful marketing and specialization.
} 
Finally, in addition to these variables, there is a question of whether the initial level of commercialization, which measures the degree of integration into the markets, should be used as an independent variable. The commercialization ratio could be endogenous, determined by other variables that also determine the level of income and its growth and in the case of Vietnam that turned out to be true. Initial level of commercialization was correlated with other variables, both household characteristics and some service variables that determine income growth. For this reason, we did not include commercialization among the independent variables in the regressions.

A similar question arises with the use of access to credit variables, and whether they are endogenous. One could argue that the households who are better endowed in both human and physical capital would have greater access to credit. This relationship was tested and the initial access to credit variable was not correlated with the other independent variables both for 1993 and 1998. Therefore, we used it as an independent variable. $^{25}$

\subsection{Empirical Methodology}

We adopt a reduced form approach $^{26}$ to econometrically estimate the effect of household and service variables on income growth, or the rate of income response to the reforms. In particular, exploiting the panel nature of our data we use the initial household characteristics (endowments), initial access to and quality of major services as our independent variables. As these initial variables are predetermined, any questions about simultaneity is avoided. The dependent variable is the percentage change in household real income $(\log \text { difference })^{27}$. We also estimate another model where in addition to the above independent variables we use proxies for the changes in access to some of the

\footnotetext{
${ }^{25}$ Of course, this does not explain whether the households are credit constrained or that they did not decide to make use of credit because of lack of investment opportunities. Here we are assuming that the households are credit constrained. We are grateful to the referee for pointing this out.

${ }^{26}$ The specification is similar to that of Dercon (2005).

${ }^{27} \mathrm{We}$ also experimented with using agricultural and non-agricultural income separately as the dependent variables. The preliminary results show that the variables that determine different sources of income could be different. However, there are serious questions about the nature of the interdependence among different sources of income that prohibit simple analyses. And the elaboration of these relationships takes us away from the basic issues raised in this paper.
} 
services just to illustrate their relation to income growth without making a claim on causality. Formally, our specification is as follows:

$$
\begin{aligned}
& \Delta \log y_{h, t}=\alpha+\beta X_{h, 1993}+\varepsilon_{h, t} \\
& \Delta \log y_{h, t}=\gamma+\lambda X_{h, 1993}+\delta \Delta X_{h}+\eta_{h, t}
\end{aligned}
$$

where $\mathrm{X}$ is the matrix of initial household characteristics (endowments) and the access to and quality of major services (i.e. household size, age, education, gender, land and region, access to electricity, public transportation, whether household received technical advice from government, importance of credit. See Table A.3 for more detailed descriptions). In addition, $\Delta X_{h}$ is the matrix of the change in access to important services (i.e. change in electricity access, proxy for change in credit access, etc.). Our main specification allows us to examine the relation between initial characteristics, services, endowments, and the change in welfare, while the second specification allows to speculate on the returns to changes in certain assets and characteristics. The second specification is similar to a first-differenced estimation with the obvious inclusion of level variables in our case. Since we are using a difference model, the time invariant factors are also controlled for. We estimate this model using Ordinary Least Squares (OLS). The standard errors are corrected for clustering and survey design ${ }^{28}$ (Deaton, 1997) with communes as our clusters to take into account the fact that households in the same commune may not be independent, as they have access to similar conditions. Therefore, our coefficients are robust.

We estimate our specification for four different set of variables to better highlight and understand the contribution of each set. The third model, which corresponds to our basic model and is the main specification for the relationship, includes both the initial household characteristics and initial service variables. The first two specifications are provided only to illustrate the relative contribution of household characteristics and service variables and should be interpreted in that way. Lastly we add our proxies for

\footnotetext{
${ }^{28}$ Van de Walle \& Cratty (2003) maintain that the panel households are representative of the country. Since the survey design included two strata rural and urban, we consider our panel to be representative of the rural areas in Vietnam and do not use weights.
} 
changes in access to service. Although there are endogeneity problems with this specification, we still present it for information. Results of our estimation are provided in Table A. 1 in the Annex.

\subsection{Results}

As expected, the regressions show that both initial household characteristics and access to services are important in explaining real income growth in rural Vietnam. Households that have larger families initially experienced higher income growth. In addition, the education level of the household head has an increasingly positive impact on growth. The better educated the household head the higher is the income growth. Surprisingly, the age of the household head seemed to negatively impact the growth. Although, age is generally thought to be capturing the experience in this case, experience seemed to have an inverse impact. The households with a greater initial capital stock (i.e. farm implements, livestock, and transport related durables) experienced a higher growth. This is not surprising as these households are more likely to be in a better position to respond more positively to the reforms, thus reaping more of the benefits ${ }^{29}$. Also the households where the household head's occupation is not agriculture had significantly higher growth. The initial income level is significant and negative, indicating a strong catch up effect ( $\beta$-convergence).

Although the share of cash crop income turned out to be not significant, it is not so unexpected as the growth in cash crop is limited to specific regions (specifically, Central Highlands, and Southeast), and has been the driving force for growth ${ }^{30}$ only in these regions. More importantly, this may be due to the fact that in most of Vietnam the expansion of rice trade acted as a cash crop which also shows that the income growth can be triggered by the expansion of basic food commodities, if the comparative advantage can be generated and sufficient price increase can take place.

\footnotetext{
${ }^{29}$ Lopez, Nash and Stanton (1995) find that farmers with more productive assets (farm implements, vehicles etc.) are more likely to respond positively to price changes, using Mexican farm survey data.

${ }^{30}$ In fact when we estimate our model for only Central Highlands and Southeast, we find that the initial share of cash crop income is positive and significant.
} 
Although there has been a huge expansion in the agricultural sector in rural areas, the initial land size does not seem to have an impact on overall income growth. This may be explained by the fact that the expansion has been broad based that is a large expansion also occurred in the non-agricultural sector. Although land size is very important for agricultural income, the fact is that income growth was not all due to agriculture. In fact when we estimate a similar equation for agricultural income growth we find that initial land size is positive and significant.

The regional dummies illustrate the unexplained impact of the locational variables. Both the South East and the Mekong Delta had higher growth rates than the other regions. The intuitive explanation is that these regions are the places where rice production increased the most. Yet adding the share of rice in income, land allocated to rice, etc. as independent variables did not explain the higher growth rates.

The service variables that we focus are the ones that are conjectured to have a potential impact on production either through productivity or through increased market participation. Since the data requirements are much larger hence harder to fulfill for variables affecting productivity, most of the variables considered here are those that are believed to have an impact on transaction costs (especially fixed costs, see Goetz, 1992; Key, Sadoulet, and de Janvry, 2000) such as roads or quality of roads, public transportation, access to credit, extension services, availability of markets, and communication services.

The results show that, although most of the service variables have a positive and significant effect on growth in income (contributing to the positive response to reforms), some that are expected to have impact are not significant. More specifically, households that had electricity in their homes initially had higher growth rates (1.2\% more) compared to those that did not. The quality of roads were also important; households who had access to roads that are always passable or to waterways experienced better growth than those who had access to partially passable roads. Moreover, as the degree of impassability increased the growth rate decreased. On the other hand, having access to public transportation does not seem to impact growth. In terms of the availability of markets, living in a commune where there is an established daily market contributed positively to growth. This is not surprising as the presence of daily markets (even if they 
are just food markets), provide a venue for households to sell their products; it also provides a place for diversified households to buy the staple product and eliminate some of the food security issues, allowing them to respond better to reforms ${ }^{31}$.

Access to credit for agricultural production (as proxied by the share of agricultural credit in income) affects the income growth positively as well. Households that had taken a higher share of agricultural credit experienced greater income growth rates. We also wanted to investigate whether for different groups of households (poor, middle income, rich) access to agricultural credit had a different impact in growth. When we created interaction variables for the share of agricultural income variable with poor, middle, and rich dummies, we found that poor and middle income households experienced more growth for an incremental increase in share of agricultural income compared to rich households (1\% and $1.1 \%$ more respectively). Recognizing that an incremental increase in shares amounts to a much lower increase in amount of credit for poor households, we may deduce that the poor used their credit better. Hence the increased access to credit has most likely been pro-poor.

In terms of technical advice, the availability or location of the extension center or its activities did not contribute to the growth rates ${ }^{32}$. However, the households who had received advice from the government agencies on agricultural activities did much better. So, it is not the existence of the support institution but the individual's interaction with the service agency that seems to be important. Also the fact that agricultural extension centers were present only in a small share of communes initially may be another reason for its insignificance.

The change variables included in Model 2 indicate that changes in electricity access and access to credit are all positively correlated with income growth. Although we do not claim causality due to endogeneity issues, we think it is instructive to present them.

\footnotetext{
${ }^{31} \mathrm{We}$ also experimented with the distance to daily market variable to capture some of the initial transaction costs and got similar results.

${ }^{32}$ We experimented with availability of the agricultural extension center (dummy), services provided, in addition to whether an extension agent visited in the past year, but they were all insignificant and the opposite sign of what we would expect.
} 


\section{CONCLUDING REMARKS}

This paper examined the role of services on households' response to trade reform for the case of Vietnam. In particular, we investigated whether initial availability and quality of services had an impact on the income growth households experienced after a major trade liberalization in rice marketing. Our results were mostly in line with the theoretical literature; service availability and quality allows households to better respond to incentives created by the reform and take advantage of the benefits. However, some services that are conjectured to be important turned out not to have an impact in this case. This can be explained by the extensive coverage of infrastructure services in Vietnam. Among the services that had a positive impact on income growth are: access to electricity, to daily markets, and to credit, and quality of roads. On the other hand, extension services, public transportation, and communication services were not important in income growth. When service availability is very similar across different localities, household characteristics become more important in determining the response.

Although one would need to compare the results (and coverage of services) for Vietnam to other countries with similar reforms to be able to derive strong policy recommendations, these results are still instructive. They suggest that availability of production related services contribute positively to the impact of trade reforms. The remarkably rapid growth in Vietnam is exceptional as is the initial service coverage. In fact if it were possible to observe the same reform without the initial service coverage, we would conjecture that the response would be less prominent. Thus, provision of services may be thought of as complementary domestic policy to potential trade reforms.

This paper set out to investigate the role of services (if any) on household welfare in response to a trade reform. It is the first attempt to see if conjectures in theoretical literature for infrastructure and household behavior apply to trade reforms. More research needs to be done to identify the channels through which services contribute. In addition, identifying the impact of each channel would help in generating clearer policy implications. In that respect, better differentiation of households and regions is needed to separate the effect of household characteristics from the locational variables.

Comparison of the rapid response in Vietnam to other countries that experienced trade 
reforms and have differential level of services (i.e. China, India, Bangladesh etc.) would be very important in determining the exact contribution of services and would allow us to be more precise about which services play a more significant role. It would also allow us to investigate why Vietnam had such a positive and rapid response. 


\section{References:}

Balat, J.F. and G.G. Porto. 2005. "The WTO Doha Round, Cotton Sector Dynamics, and Poverty Trends in Zambia.” mimeo, World Bank, Washington, D.C.

Balat, J.F. and G.G. Porto. 2006. "Commodity Exports, Income Growth and Poverty. The Role of Household Constraint in Agriculture.” mimeo, World Bank, Washington D.C.

Benjamin, D. and L. Brandt. 2004. “Agriculture and Income Distribution in Rural Vietnam under Economic Reforms: A Tale of Two Regions”. In Glewwe, P., N. Agrawal, and D. Dollar (Eds) "Economic Growth, Poverty and Household Welfare in Vietnam", World Bank, pp. 133-186.

Brambilla, I. and G. Porto. 2005. "Farm productivity and market structure: evidence from cotton reforms in Zambia." mimeo, Yale University.

Cadot, O., L. Dutoit, and M. Olarreaga. 2005. "Subsistence farming, adjustment costs and agricultural prices: evidence from Madagascar." mimeo, University of Lausanne.

Deaton, Angus. 1997. “The Analysis of Household Surveys: a Microeconometric Approach to Development Policy", Johns Hopkins University Press. Baltimore.

Dercon, S. 2005. "Economic reform, growth and the poor: Evidence from rural Ethiopia." Journal of Development Economics, (forthcoming).

De Janvry, A., M. Fafchamps, and E. Sadoulet. 1991. "Peasant Household Behavior with Missing Markets.” The Economic Journal, 101(409): 1400-17.

Diop, N. 2005. "Trade Costs, Export Development and Poverty in Rwanda." Diagnostic Trade Integration Study for Rwanda, World Bank, Washington D.C.

Duygan, B. 2005. "How can increased trade help poor households in Tanzania? Identifying the role of trade, trade policy, and market access." Diagnostic Trade Integration Study for Tanzania, World Bank, Washington D.C. 
Goetz, S. 1992. "A Selectivity Model of Household Food Marketing Behavior in SubSahara Africa." American Journal of Agricultural Economics, 74(2): 444-452.

Goldberg, P. and N. Pavcnik. 2004. "Trade, Inequality, and Poverty: What Do We Know? Evidence from Recent Trade Liberalization Episodes in Developing Countries." Brookings Trade Forum, 223-269.

Glewwe, P., M. Gragnolati, and H .Zaman. 2000. "Who gained from Vietnam's boom in the 1990's? An Analysis of Poverty and Inequality Trends." World Bank Policy Research Working Paper Series No: 2275.

Isik-Dikmelik, A. 2006. "Trade Reforms and Welfare: An Ex-Post Decomposition of Income in Vietnam.” World Bank Policy Research Working Paper Series No: 4049.

Key, N., E. Sadoulet, and A. De Janvry. 2000. "Transaction Costs and Agricultural Household Supply Response." American Journal of Agricultural Economics, 82(2): 245259.

Lopez, R., J. Nash, and J. Stanton. 1995. “Adjustment and Poverty in Mexican Agriculture: How Farmers' Wealth Affects Supply Response.” World Bank Policy Research Working Paper Series No: 1494.

Mitchell, D., 2004. "Background note on agriculture" Diagnostic Trade Integration Study for Tanzania, World Bank, Washington D.C.

Nicita, A. 2006. "Availability of Services, Transaction Costs and Market Participation. Evidence from rural Madagascar." mimeo, World Bank, Washington D.C.

Nicita, A. 2004. "Who benefited from trade liberalization in Mexico? Measuring the effects on household welfare." World Bank Policy Research Working Paper Series No: 3265 . 
Niimi, Y., P. Vasudeva-Dutta, and L.A. Winters. 2003. "Trade Liberalization and Poverty Dynamics in Vietnam.” Poverty Research Unit at Sussex Working Paper No: 17.

Reimer, J. J. 2002. "Estimating the Poverty Impacts of Trade Liberalization." World Bank Policy Research Working Paper Series No: 2790.

Porto, G. 2003. 'Trade reforms, market access and poverty in Argentina." World Bank Policy Research Working Paper Series No: 3135.

Van De Walle, D. and D. Cratty. 2003. "Is the Emerging Non-Farm Market Economy the Route Out of Poverty in Vietnam?" World Bank Policy Research Working Paper Series No: 2950. 


\section{ANNEX}

Figure A.1a-A.1f. Average Market Integration Variables by availability Quality of Roads in 1993
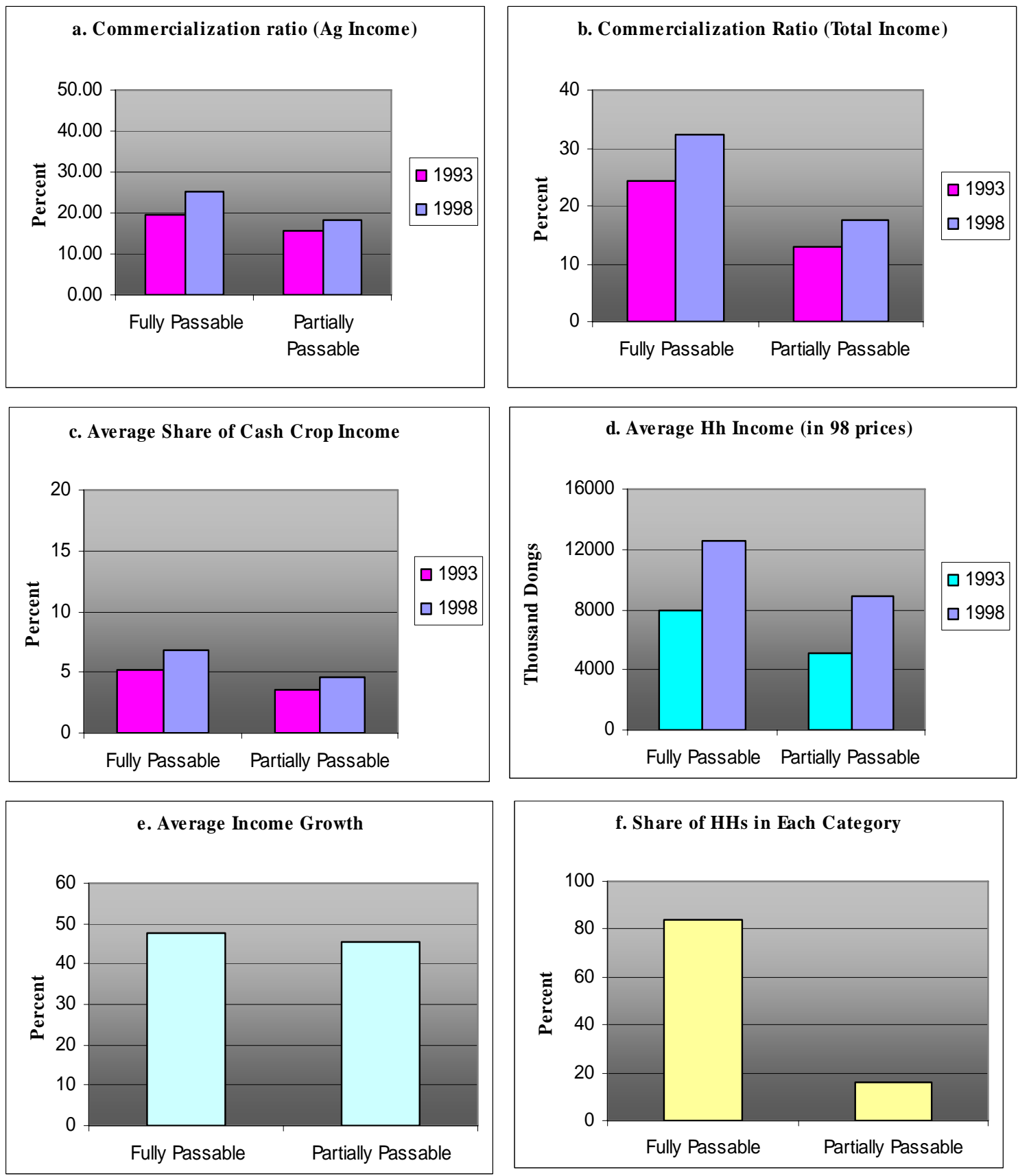


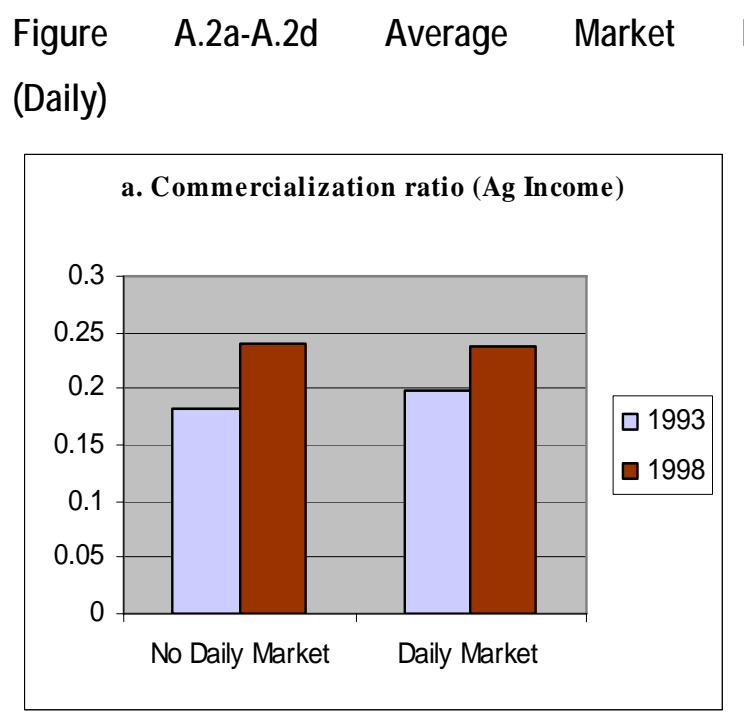

Integration by availability of Markets
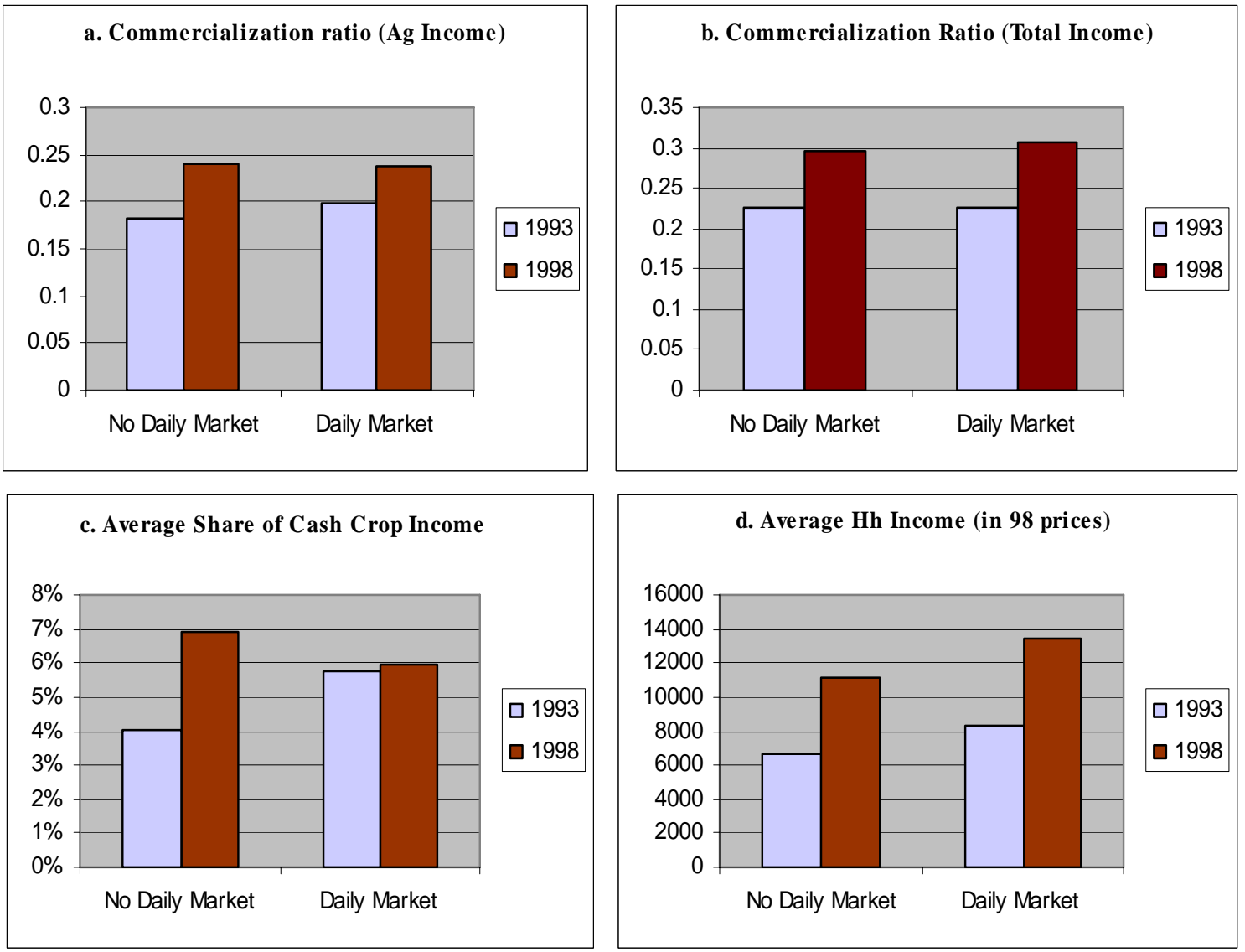


\section{Table A.1 Regression Results}

Dependent variable: percentage growth in real income.

\begin{tabular}{|c|c|c|c|c|}
\hline & Specification1 & Specification2 & $\begin{array}{l}\text { Specification3 } \\
\text { Model } 1\end{array}$ & $\begin{array}{l}\text { Specification4 } \\
\text { Model } 2\end{array}$ \\
\hline \multicolumn{5}{|l|}{ Initial Characteristics } \\
\hline \multicolumn{5}{|l|}{ Household Characteristics \& Endowments } \\
\hline \multirow[t]{2}{*}{ Log of Initial income level } & -0.744 & & -0.773 & -0.78 \\
\hline & {$[0.031]^{\star \star *}$} & & {$[0.027]^{\star \star *}$} & {$[0.026]^{\star \star \star}$} \\
\hline \multirow[t]{2}{*}{ Log of Household size } & 0.356 & & 0.309 & 0.316 \\
\hline & {$[0.049]^{\star \star *}$} & & {$[0.042]^{\star \star *}$} & {$[0.042]^{\star \star \star}$} \\
\hline \multirow[t]{2}{*}{ Age of $\mathrm{HH}$ Head } & -0.003 & & -0.003 & -0.003 \\
\hline & {$[0.001]^{\star *}$} & & {$[0.001]^{\star \star \star}$} & {$[0.001]^{\star \star \star}$} \\
\hline \multirow[t]{2}{*}{ Gender of HH Head (1=male) } & 0.005 & & 0.015 & 0.016 \\
\hline & {$[0.038]$} & & {$[0.036]$} & {$[0.036]$} \\
\hline \multicolumn{5}{|l|}{$\begin{array}{l}\text { Highest Diploma Obtained by HH Head (No Diploma } \\
\text { Dummy is Omitted) }\end{array}$} \\
\hline \multirow[t]{2}{*}{ Primary or Lower Secondary } & 0.122 & & 0.185 & 0.166 \\
\hline & {$[0.040]^{\star \star *}$} & & {$[0.036]^{\star * *}$} & {$[0.036]^{\star \star \star}$} \\
\hline \multirow[t]{2}{*}{ Upper Secondary or Vocational High School } & 0.103 & & 0.213 & 0.197 \\
\hline & {$[0.057]^{\star}$} & & {$[0.053]^{\star \star *}$} & {$[0.051]^{\star \star \star}$} \\
\hline \multirow[t]{2}{*}{ Undergraduate and More } & 0.448 & & 0.513 & 0.485 \\
\hline & {$[0.155]^{\star \star \star}$} & & {$[0.146]^{\star \star \star}$} & {$[0.142]^{\star \star \star}$} \\
\hline \multicolumn{5}{|l|}{ Economic Characteristics } \\
\hline \multirow[t]{2}{*}{ Log Land size } & 0.009 & & 0.003 & 0.003 \\
\hline & {$[0.012]$} & & {$[0.011]$} & {$[0.011]$} \\
\hline \multirow[t]{2}{*}{ Share of cash crop income } & 0.305 & & 0.228 & 0.211 \\
\hline & {$[0.200]$} & & {$[0.138]$} & {$[0.132]$} \\
\hline \multicolumn{5}{|l|}{$\begin{array}{l}\text { Industry of HH Head dummies (Agriculture Dummy } \\
\text { Omitted) }\end{array}$} \\
\hline \multirow[t]{2}{*}{ Non Agricultural } & 0.218 & & 0.179 & 0.176 \\
\hline & {$[0.050]^{\star \star \star}$} & & {$[0.049]^{\star \star \star}$} & {$[0.050]^{\star \star \star}$} \\
\hline \multirow[t]{2}{*}{ Log of Capital (assets owned by the household) } & 0.095 & & 0.099 & 0.095 \\
\hline & {$[0.017]^{\star \star \star}$} & & {$[0.015]^{\star \star \star}$} & {$[0.015]^{\star \star \star}$} \\
\hline \multicolumn{5}{|l|}{ Services } \\
\hline \multicolumn{5}{|l|}{$\begin{array}{l}\text { Regional Characteristics (Northern Uplands dummy } \\
\text { omitted) }\end{array}$} \\
\hline \multirow[t]{2}{*}{ Red River Delta } & & -0.145 & -0.071 & -0.086 \\
\hline & & {$[0.119]$} & [0.109] & [0.109] \\
\hline \multirow[t]{2}{*}{ North Central Coast } & & 0.233 & 0.11 & 0.113 \\
\hline & & {$[0.098]^{\star *}$} & {$[0.109]$} & [0.102] \\
\hline
\end{tabular}




\begin{tabular}{|c|c|c|c|c|}
\hline & Specification1 & Specification2 & $\begin{array}{l}\text { Specification3 } \\
\text { Model } 1\end{array}$ & $\begin{array}{c}\text { Specification4 } \\
\text { Model } 2\end{array}$ \\
\hline \multirow[t]{2}{*}{ South Central Coast } & & 0.2 & 0.104 & 0.072 \\
\hline & & {$[0.103]^{*}$} & {$[0.104]$} & {$[0.104]$} \\
\hline \multirow[t]{2}{*}{ Central Highlands } & & 0.237 & 0.377 & 0.302 \\
\hline & & {$[0.218]$} & {$[0.274]$} & {$[0.244]$} \\
\hline \multirow[t]{2}{*}{ South East } & & 0.344 & 0.485 & 0.445 \\
\hline & & {$[0.109]^{\star \star \star}$} & {$[0.117]^{\star \star \star}$} & {$[0.112]^{\star \star *}$} \\
\hline \multirow[t]{2}{*}{ Mekong Delta } & & 0.098 & 0.393 & 0.421 \\
\hline & & {$[0.105]$} & {$[0.099]^{\star \star *}$} & {$[0.091]^{\star \star \star}$} \\
\hline \multicolumn{5}{|l|}{ Service Access \& Quality } \\
\hline \multirow[t]{2}{*}{ Electricity access (1=yes) } & & -0.02 & 0.157 & 0.267 \\
\hline & & {$[0.050]$} & {$[0.057]^{\star \star \star}$} & {$[0.073]^{\star \star \star}$} \\
\hline \multirow[t]{2}{*}{ Road Quality (Months Impassable) when no waterway } & & -0.005 & -0.025 & -0.021 \\
\hline & & {$[0.010]$} & {$[0.012]^{\star \star}$} & {$[0.012]^{*}$} \\
\hline \multirow[t]{2}{*}{ Public Transportation (1=yes) } & & -0.028 & 0.004 & 0.002 \\
\hline & & {$[0.072]$} & {$[0.070]$} & {$[0.065]$} \\
\hline \multirow[t]{2}{*}{ Daily market (1=yes) } & & 0.093 & 0.14 & 0.119 \\
\hline & & {$[0.079]$} & {$[0.071]^{*}$} & {$[0.070]^{*}$} \\
\hline \multirow[t]{2}{*}{ Distance to Agricultural Extension center } & & -0.002 & 0.001 & 0.001 \\
\hline & & {$[0.001]$} & {$[0.002]$} & {$[0.001]$} \\
\hline \multirow[t]{2}{*}{ Share of agricultural Loan in Income } & & 0.282 & 0.07 & 0.068 \\
\hline & & {$[0.040]^{\star \star \star}$} & {$[0.028]^{\star \star}$} & {$[0.027]^{\star \star}$} \\
\hline \multirow[t]{2}{*}{ Advice from government (1=yes) } & & 0.096 & 0.112 & 0.097 \\
\hline & & {$[0.056]^{\star}$} & {$[0.046]^{\star \star}$} & {$[0.046]^{\star \star}$} \\
\hline \multirow[t]{2}{*}{ Communication Services } & & -0.037 & -0.105 & -0.11 \\
\hline & & {$[0.079]$} & {$[0.081]$} & {$[0.074]$} \\
\hline \multicolumn{5}{|l|}{ Change in access } \\
\hline \multirow[t]{2}{*}{ Change in Electricity access } & & & & 0.168 \\
\hline & & & & {$[0.055]^{\star \star \star}$} \\
\hline \multirow[t]{2}{*}{ Change in Loan } & & & & 0 \\
\hline & & & & {$[0.000]^{\star \star \star}$} \\
\hline \multirow[t]{2}{*}{ Constant } & 5.557 & 0.337 & 5.603 & 5.61 \\
\hline & {$[0.248]^{\star \star \star}$} & {$[0.083]^{\star \star \star}$} & {$[0.232]^{\star \star \star}$} & {$[0.226]^{\star \star \star}$} \\
\hline Observations & 3012 & 3256 & 3012 & 3012 \\
\hline R-squared & 0.36 & 0.07 & 0.41 & 0.42 \\
\hline
\end{tabular}

1) Cluster corrected, robust standard errors in brackets

2 ) $*$ significant at $10 \% ; * *$ significant at $5 \% ; * * *$ significant at $1 \%$ 
Table A.2 Descriptive Statistics of Variables

\begin{tabular}{|lcc|}
\hline Variables & Mean & Std. dev \\
\hline Percent Income Growth & 0.473 & 0.92 \\
Log of Initial income level & 8.567 & 0.88 \\
Log of Household size & 1.526 & 0.46 \\
Age of HH Head & 45.063 & 14.75 \\
Gender of HH Head (1=male) & 0.784 & 0.41 \\
Primary or Lower Secondary & 0.488 & 0.50 \\
Upper Secondary or Vocational High School & 0.105 & 0.31 \\
Undergraduate and More & 0.007 & 0.08 \\
Log Land size & 7.908 & 1.74 \\
Share of cash crop income & 0.049 & 0.22 \\
Industry if HH Head, Non Agricultural & 0.132 & 0.34 \\
Log of Capital (assets owned by the household) & 7.002 & 1.34 \\
Red River Delta & 0.237 & 0.43 \\
North Central Coast & 0.156 & 0.36 \\
South Central Coast & 0.104 & 0.31 \\
Central Highlands & 0.035 & 0.18 \\
South East & 0.082 & 0.27 \\
Mekong Delta & 0.213 & 0.41 \\
Electricity access (1=yes) & 0.360 & 0.48 \\
Road Quality (Months Impassable) when no waterway & 0.764 & 2.42 \\
Public Transportation (1=yes) & 0.508 & 0.50 \\
Daily market (1=yes) & 0.508 & 0.50 \\
Distance to Agricultural Extension center & 12.312 & 15.14 \\
Share of agricultural Loan in Income & -0.008 & 4.52 \\
Commercialization Index (agriculture) & 0.190 & 0.16 \\
Advice from government (1=yes) & 0.458 & 0.50 \\
Communication Services & 0.320 & 0.47 \\
Change in Electricity access & & 0.48 \\
Change in Loan & 7049.19 \\
Change in commercialization index (agricultural income) & 0.18 \\
\hline
\end{tabular}


Table A.3 Descriptions of Variables Used

\begin{tabular}{|c|c|}
\hline Variable & Description \\
\hline \multicolumn{2}{|l|}{ Initial Characteristics } \\
\hline \multicolumn{2}{|l|}{ Household Characteristics \& Endowments } \\
\hline Initial income level & $\begin{array}{l}\text { Logarithm of initial Households Income (in } 98 \text { prices). To capture } \\
\text { the catch-up effect in the growth. }\end{array}$ \\
\hline Household size & Logarithm of household size \\
\hline Age & Household Head's Age \\
\hline Gender dummy & Household Head's gender (1=Male) \\
\hline Education Dummies & $\begin{array}{l}\text { Dummies for the highest Diploma Obtained of the of the Household } \\
\text { Head }\end{array}$ \\
\hline Education1 & $1=$ if household head doesn't have any diploma \\
\hline Education2 & $\begin{array}{l}\text { 1=If household head holds only Primary or Lower Secondary } \\
\text { diploma, } 0=\text { otherwise }\end{array}$ \\
\hline Education3 & $\begin{array}{l}\text { 1= if household head holds only Upper Secondary or Vocational } \\
\text { High School Diploma, } 0=\text { otherwise }\end{array}$ \\
\hline Education4 & $\begin{array}{l}\text { 1=If household head holds at least an undergraduate degree, } \\
0=\text { otherwise }\end{array}$ \\
\hline Land size & Logarithm of land owned by the household (m2) \\
\hline Share of cash crop income & $\begin{array}{l}\text { Share of profit from cash crop income in total income for the } \\
\text { household }\end{array}$ \\
\hline \multicolumn{2}{|l|}{ Industry of HH Head dummies } \\
\hline Agricultural & Household head works in Agricultural Industry \\
\hline Non Agricultural & Household Head works in Non-Agricultural Industry \\
\hline Capital & $\begin{array}{l}\text { The logarithm of assets owned by the household. The assets } \\
\text { include, the value of all livestock, farm equipment, and } \\
\text { transportation equipment (car, motorbike, and bicycle) owned by } \\
\text { the household in } 1993 .\end{array}$ \\
\hline \multicolumn{2}{|l|}{ Services } \\
\hline Region Dummies & To proxy for other (unobserved) service variables \\
\hline NU & $1=$ Northern Uplands, $0=0$ therwise \\
\hline RR & 1= Red River Delta, $0=$ otherwise \\
\hline NCC & $1=$ North Central Coast, $0=0$ therwise \\
\hline $\operatorname{sCC}$ & $1=$ South Central Coast, $0=0$ therwise \\
\hline $\mathrm{CH}$ & $1=$ Central Highlands, $0=0$ otherwise \\
\hline SE & $1=$ Southeast, $0=$ otherwise \\
\hline MD & $1=$ Mekong Delta, $0=0$ therwise \\
\hline
\end{tabular}




\begin{tabular}{|ll|}
\hline Variable & \\
\hline Electricity-household & Whether household have access to electricity at home or not \\
Road quality and waterways & $\begin{array}{l}\text { The quality of the road as measured by the number of months } \\
\text { impassable in a year, when there is no access to waterways. } \\
\text { Public Transportation }\end{array}$ \\
Whether household lives in a commune with access to public \\
transportation
\end{tabular}

